\title{
Surprising New Height Regulating Genes: Beyond Growth Hormone and IGF-I
}

$\mathrm{S}^{\mathrm{ta}}$ ature has been the subject of quantitative genetic analysis since the nineteenth century. A century ago it was proposed that height exhibits multifactorial inheritance, representing what are now called polygenic traits, and today, it is recognized that height is highly heritable. In fact, in modern western societies only $20 \%$ of the variation in height is attributable to environmental factors, although the other $80 \%$ is genetically determined. The role of the growth hormone $(\mathrm{GH})$ and IGF (IGF) in regulating mammalian height has been widely appreciated and commonly termed the "somatomedin hypothesis." Furthermore, multiple mutations in the genes in the GH-IGF axis cause rare syndromes with extreme stature abnormalities (1).

During the last two years genome wide association (GWA) has been used to identify genetic factors that influence health and disease. GWAs use extensive arrays of single nucleotide polymorphisms (SNPs) that can identify common variations across the human genome and are designed to identify genetic associations with observable traits. Such studies involve genotyping thousands of cases and controls at over $10^{5}$ SNPs markers spread throughout the genome and then looking for associations between the genotypes at each locus and disease or condition status. Associations in large population cohorts facilitate the identification of risk alleles, which allows for subsequent characterization of the relevant variations in the human genome.

Recently, several landmark studies using GWA have demonstrated novel genes involved in the risk for a number of diseases and conditions. Interestingly, one of the first articles published using the GWA technique, examined the size of dogs. In this study, an examination of 463 domestic dogs identified the IGF-1 promotor region within chromosome 15 as the most critical quantitative trait locus determining size in dogs (2). This result validated the concept that the IGF system is critical for growth in mammals, which had been previously shown in mouse knockouts and human mutational analysis Thus, it came as a complete surprise to everyone in the field when SNPs, associated with height were reported in the journal Nature Genetics in May 2008 (3-5). Three separate studies found multiple loci that correlated with height at high levels of statistical confidence and identified over 50 polymorphic genes that determine height variability within the normal population, none of which has been previously linked to mammalian growth. Only a few of these SNPs were identified in all three studies and one of these was the rather obscure gene, High-Mobility-Group-A2 (HMGA2). The common variation within HMGA2, a DNA-binding protein sheds some light on this paradigm because the mouse knockout is large and a human mutation is associated with overgrowth as well as cancer. Although the two alleles of the polymorphism of HMGA2 and other identified height-modulating genes are associated with a difference in height of only about $0.5 \mathrm{~cm}$ per allele, the effect is additive, which means that the right combination of alleles can result in a substantial height difference between individuals. Although the identification of SNPs associated with height was surprising, the bigger surprise was that none of the "usual suspects," i.e., GH-IGF variations, were identified.

It is possible that GH-IGF variations are only important in rare severe defects of short stature, but this is unlikely, given the observations of variations in this biochemical pathway in the normal population accounting for height variability. Much has been written about the potential for false positives with the GWA technique and in spite of the stringent statistical screens, only validation in independent studies will be fully convincing. However, the possibility of false negatives is also important here because it is possible that the current arrays being used for GWA are missing important genes because of inadequate SNP markers in critical chromosomal regions.

Regardless of the controversy, these studies demonstrate the enormous potential of genomic technology to unravel the role of multiple genes and biologic pathways not previously known to regulate height and/or height-related syndromes. These GWA findings will undoubtedly spike a new era in research related to human growth and its disorders, and could lead to additional discoveries that may improve the development of new diagnostics and better treatments. - Maria Isabel Hernández and Pinchas Cohen

\section{REFERENCES}

1. Kaplan SA, Cohen P 2007 The Somatomedin hypothesis: fifty years later. J Clin Endocrinol Metab 92:4529-4535

2. Sutter NB, Bustamante CD, Chase K, Gray MM, Zhao K, Zhu L, Padhukasahasram B, Karlins E, Davis S, Jones PG, Quignon P, Johnson GS, Parker HG, Fretwell N, Mosher DS, Lawler DF, Satyaraj E, Nordborg M, Lark KG, Wayne RK, Ostrander EA 2007 A single IGF1 allele is a major determinant of small size in dogs. Science 316:112-115

3. Weedon MN, Lango H, Lindgren CM, Wallace C, Evans DM, Mangino M, Freathy RM, Perry JR, Stevens S, Hall AS, Samani NJ, Shields B, Prokopenko I, Farrall M, Dominiczak A; Diabetes Genetics Initiative; Wellcome Trust Case Control Consortium, Johnson T, Bergmann S, Beckmann JS, Vollenweider P, Waterworth DM, Mooser V, Palmer CN, Morris AD, Ouwehand WH; Cambridge GEM Consortium, Zhao JH, Li S, Loos RJ, Barroso I, Deloukas P, Sandhu MS, Wheeler E, Soranzo N, Inouye M, Wareham NJ, Caulfield M, Munroe PB, Hattersley AT, McCarthy MI, Frayling TM 2008 Genome-wide association analysis identifies 20 loci that influence adult height. Nat Genet 40:575-583

4. Gudbjartsson DF, Walters GB, Thorleifsson G, Stefansson H, Halldorsson BV, Zusmanovich P, Sulem P, Thorlacius S, Gylfason A, Steinberg S, Helgadottir A, Ingason A, Steinthorsdottir V, Olafsdottir EJ, Olafsdottir GH, Jonsson T, Borch-Johnsen K, Hansen T, Andersen G, Jorgensen T, Pedersen O, Aben KK, Witjes JA, Swinkels DW, den Heijer M, Franke B, Verbeek AL, Becker DM, Yanek LR, Becker LC, Tryggvadottir L, Rafnar T, Gulcher J, Kiemeney LA, Kong A, Thorsteinsdottir U, Stefansson K 2008 Many sequence variants affecting diversity of adult human height. Nat Genet 40:609-615

5. Lettre G, Jackson AU, Gieger C, Schumacher FR, Berndt SI, Sanna S, Eyheramendy S, Voight BF, Butler JL, Guiducci C, Illig T, Hackett R, Heid IM, Jacobs KB, Lyssenko V, Uda M; Diabetes Genetics Initiative; FUSION; KORA; Prostate, Lung Colorectal and Ovarian Cancer Screening Trial; Nurses' Health Study; SardiNIA, Boehnke M, Chanock SJ, Groop LC, Hu FB, Isomaa B, Kraft P, Peltonen L, Salomaa V, Schlessinger D, Hunter DJ, Hayes RB, Abecasis GR, Wichmann HE, Mohlke KL, Hirschhorn JN 2008 Identification of ten loci associated with height highlights new biological pathways in human growth. Nat Genet 40:584-591 